\title{
Pembiasaan Membentuk Karaktek Peserta Didik Madrasah Miftahul Huda Musi Rawas Utara
}

\author{
Mujahidatul Haibah*, Hasan Basri, Mohamad Eri Hadiana, Tarsono \\ Universitas Islam Negeri Sunan Gunung Djati, Indonesia \\ Jl. Cimencrang, Kec. Gedebage, Kota Bandung, Jawa Barat-40292 \\ Email: ajamihunda@gmail.com
}

\begin{abstract}
The problem of this research is to reveal the problems that occur about some of the characters of students at Madrasah Miftahul Huda Musi Rawas Utara. While the purpose of this study was to determine the habituation in shaping the character of students at Madrasah Miftahul Huda Musi Rawas Utara. Then the method in this research is descriptive qualitative. So from that the results obtained from this study include character education which includes applying first, the value of worship such as congregational prayers, sunnah prayers, reading the Qur'an, and giving alms. Second, refracting individual personalities such as speaking honestly, polite, disciplined, and helpful. The three supporting factors are from the efforts of educators and the willingness of students by means of exemplary methods. The inhibiting factor is from the environment and individuals who have not been able to control their willingness to live freely. The conclusion is that it is added to maximize the habituation of character formation by applying the habituation of worship values and personality in everyday life.
\end{abstract}

Keywords: Education, Character, Students

Abstrak: Masalah penelitian ini adalah mengungkapkan masalah yang terjadi tentang beberapa karakter peserta didik di madrasah Miftahul Huda Musi Rawas Utara. Sedangkan tujuan dari penelitian ini untuk mengetahui pembiasaan dalam membentuk karakter peserta didik di madrasah Miftahul Huda Musi Rawas Utara. Kemudian metode dalam penelitian ini yaitu deskriptif kualitatif. Maka dari itu didapatkan hasil dari penelitian ini yaitu pendidikan karakter ini meliputi menerapkan pertama, nilai peribadahan seperti sholat berjama'ah, sholat sunnah, membaca Al-Qur'an, dan bersholawat. Kedua, pembiasan kepribadian individu seperti berbicara jujur, sopan santun, disiplin, dan suka menolong. Ketiga faktor yang mendukung yaitu dari Usaha pendidik dan kemauan peserta didik dengan cara metode keteladanan. Faktor penghambatnya yaitu dari lingkungan dan individu yang belum bisa mengontrol kemauannya untuk hidup bebas. Kesimpulannya yaitu dengan demikian ditambah memaksimalkan pembiasaan pembentukan karakter dengan cara menerapkan pembiasaaan nilai peribadahan dan kepribadian di kehidupan sehari-hari.

Kata Kunci: Pendidikan, Karakter, Peserta Didik

Jurnal Pendidikan Agama Islam Al-Thariqah Vol. 5, No. 2, Juli - Desember 2020

Received: 27 July 2020; Accepted 30 November 2020; Published 06 December 2020

*Corresponding Author: ajamihunda@gmail.com 


\section{PENDAHULUAN}

Negara Indonesia membutuhkan manusia yang berkualitas demi kemajuan pembangunan Negara ini. Untuk membentuk manusia yang berkualiatas disini terdapat peran pendidikan yang kuat. Rosniati Hakim (2014: 1) Terdapat dalam Pasal 3 UU No. 20 Tahun 2003 yang berbunyi pendidikan nasional membangun keahlian, membentuk karakter yang berakhlak dan mencerdaskan anak bangsa Indonesia (Undang- Undang RI No 20 Tahun 2003).

Dengan adanya pendidikan juga dapat memiliki sebuah peran yang sangat penting untuk membentuk karakter atau perilaku individu menurut Hasan Basri (2017: 2). Terkait dengan kebijakan pemerintah yang menekankan pada karakter individu demi terciptanya manusia yang berkualitas dan berakhlak. Karena Karakter itu berpikir, bertingkah laku yang menjadikan sebuah manusia mempunyai ciri untuk kehidupan bersama-sama, baik itu di masyarakat luas maupun masyarakat sempit, Individu yang bagus yaitu yang bisa menyelesaikan semua masalah dengan keputusan yang mateng dan pertanggungjawaban yang kuat.

Ada dua pengertian tentang karakter. Pertama, karakter menunjukkan bagaimana seseorang berperilaku tidak jujur, kejam, ataupun rakus, tentulah orang tersebut dianggap memiliki perilaku buruk. Sebaliknya, apabila seseorang berperilaku jujur, suka menolong, tentulah orang tersebut dianggap memiliki karakter mulia. Kedua, istilah karakter erat kaitannya dengan 'personality'. Seseorang baru bisa disebut 'orang yang berkarakter', apabila tingkah lakunya sesuai kaidah moral. Masnur Muslich (2011: 71).

Maka ditulisan ini akan dijelaskan lebih lanjut tentang pembiasaan pendidik dalam membentuk karaktek peserta didik di madrasah miftahul huda Musi Rawas Utara. Penelitian ini diharapkan dapat memberi sebuah manfaat baik dunia pendidikan maupun umum. Secara teoritis ini sebuah sumbangan pemikiran dalam pendidikan dan memperluas wawasan islam. Dan secara praktis menjadikan sebuah landasan untuk motivasi pendidikan.

\section{KONSEP TEORI}

Pendidikan asal kata dari "didik" dengan awalan "pe" dan akhiran "an" dengan arti "perbuatan" yaitu seperti sebuah cara, dan hal. Istilah pendidikan dari bahasa yunani yaitu "paedagogie" dengan arti bimbingan kepada anak Ramayulis (1994: 1).

Menurut Hasan Baharun dan Mahmudah (2018: 2) mengatakan pendidikan ini hakikatnya memberikan penanaman sikap spiritual dan membentuk sikap yang berakhlakul karimah di sekitar masyarakat. Pendidikan bukan saja tentang pengetahuan umum tetapi juga memberikan tentang tingkat ketakwaan, keimanan, dan akhlak yang baik. Sesungguhnya pendidikan tidak terlepas dari kehidupan keseharian manusia.

Pendidikan di Indonesia tentang pendidikan karakter ini masyarakat masih kurang meyakini dan menerapkan dengan optimal. Menurut Haeruddin (2019: 2) Sesungguhnya karakter itu adalah menerapkan nilai kebaikan dalam sebuah tingkah laku manusia, sehingga manusia yang sombong, pembohong, munafik dan tingkah laku buruk ini merupakan manusia yang berkarakter kurang baik atau jelek. Sedangkan yang bertingkah laku sesuai yang diperintahkan oleh Allah seperti jujur, suka menolong, berperilaku baik ini dikatakan mempunyai karakter yang bagus (Sa'adillah, 2015: 6).

Adapun istilah karakter dalam kamus besar Bahasa Indonesia (KBBI, 2012) kata "karakter" ini yaitu sebuah sifat-sifat kejiwaan, tabiat, budi pekerti dan juga akhlak. 
Istilah karakter juga menurut Syarif, et al., (2016: 6) mengatakan bahwasannya karakter itu juga bisa sama maknanya dengan perilaku atau tingkah laku manusia yang ada hubungannya dengan Tuhan Pencipta alam semesta ini, kepada pribadi sendiri, antar individu satu dengan lainnya, lingkungan sekitar, dan masyarakat luas yang diharuskan individu dapat menciptakan sikap, cara berbicara, cara pemikiran, dan bahkan perbuatan atau perilaku yang harus berdasarkan norma dan agama.

Membentuk karakteristik anak atau manusia bisa dilakukan sejak masih didalam kandungan atau saat usia dini dengan cara membiasakan dengan hal-hal positif seperti dengan perkataan jujur, perbuatan yang bermanfaat, melaksanakan kewajiban sebagai ciptaan Allah SWT. dan juga disini berperan penting adalah orang tua yaitu agar dapat memberikan contoh atau pandangan yang baik terhadap anaknya. Maka dari itu anak dari usia dini akan lebih menangkap dengan apa yang diajarkan oleh orang tua atau yang diperlihat dari orang tuanya. Saat beranjak usia sekolah karakteristik anak juga dibentuk dalam dunia pendidikan formal yaitu disekolah. Dan usia dewasapun karakteristik seseorang dibentuk oleh lingkungan dan masyarakat luas (Ira Rahmayuni Jusar).

Menurut Soleha (2015: 5) Untuk menciptakan manusia yang mempunyai karakter yang baik atau bagus maka diperlukan fasilitas, sarana atau sebuah lembaga yang mendukung baik formal maupun non formal. Baik dari pendidik, orang tua, atau masyarakat yang dapat membentuk dan mengembangkan karakter manusia yang lebih baik lagi.

Menurut Muntaqo (2018: 4) Dengan lemahnya karakter atau tingkah laku manusia atau peserta didik maka harus diberikan sebuah pendidikan yang menunjang. Pendidikan karakter sangat cocok untuk membentuk karakter peserta didik karena pendidikan karakter itu merupakan sebuah usaha dari pendidik unuk mengajarkan atau mendidik nilainilai karakter yang sesuai baik dari segi pembentukan akhlak mulia, cara bicara yang baik dan bahkan mengajarkan dari segi pengembangan emosional.

Pendidikan karakter juga bertujuan untuk membentuk kesadaran peserta didik dalam mengamalkan nilainilai etika atau moral, baik itu terhadap Allah SWT., pada individu sendiri, dan pada masyarakat luas hingga menjadi manusia yang berkarakter mulia (Rangga Sa'adillah, 2015: 6).

Pendidikan karakter merupakan tujuan terpenting dalam proses pendidikan. Selain sebagai wadah atau proses untuk membentuk pribadi anak agar menjadi pribadi yang baik. Dan juga pendidikan karakter ini suatu program penanaman nilai sebuah karakter pada peserta didik dengan mencakup tentang sebuah pengetahuan, keinginan, dan perlakuan terhadap nilai-nilai karakter itu (Tarsono, 2014: 3).

Menurut Ahmad Mubarok (2019: 1) Pendidikan karakter ini mempunyai sebuah tujuan yang penting dan harus ada pada proses pendidikan. Karena bukan saja sebagai tempat ataupun sebuah proses dalam membentuk perilaku peserta didik untuk menjadi pribadi yang posiif atau baik, dan juga pendidikan karakter ini menjadi stamina untuk mendewasakan diri dan membantu dalam mengatasi masalah-masalah .

Dalam islam pendidikan karakter ini sangat penting dan dilihat dari sebuah penekanan pendidikan akhlak yang teoritisnya harus berpedoman dengan AlQur'an dan praktisnya dengan kepribadian Nabi Muhammad SAW (2007: 4).

Dengan penjelasan diatas, karakter ini lebih cenderung kepada akhlak, moral, dan sebuah etika. Jadi dalam persepektif islam karakter atau sebuah akhlak mulia ini suatu hasil dari proses penerapan syariat seperti ibadah dan muamalah 
dengan berlandasan akidah yang kuat dan harus berpedoman pada Al-Qur'an dan As-Sunnah.

\section{METODE PENELITIAN}

Metode yang digunakan dalam penelitian adalah metode deskriptif kualitatif, Menurut Arikunto (2012: 120), Hisny Fajrussalam, Uus Ruswandi, Mohammad Erihadiana (2020: 4). Disini peneliti langsung bertindak dengan cara bekerjasama dalam setiap mengambil data secara langsung dengan guru atau pendidik. Lokasi Penelitian di Madrasah Miftahul Huda Desa Srijaya Makmur Kecamatan Nibung Kabupaten Musi Rawas Utara Sumatera Selatan fokusnya dalam kelas 4 (kelas akhir), Subjek penelitiannya adalah pendidik dan peserta didik yang akan memberikan sebuah informasi yang berkaitan langsung dengan penelitian ini.

Sumber data primer yaitu guru (pendidik) di kelas 4 (kelas akhir) dan 3 siswa (peserta didik) yang memiliki kategori karakter yang baik, sedang dan kurang baik. Sedangkan data sekundernya merupakan dokumen, bukubuku, artikel, dan jurnal ilmiah.

Menurut Sugiono (2012: 138) Teknik pengumpulan data melalui; pertama, wawancara. Wawancara kepada pendidik selaku yang memberikan pembentukan karakter peserta didik khususnya pendidik yang memegang penuh kelas 4 (kelas akhir) dan juga kepada peserta didik yang memperbaiki karakternya, khususnya yang pertama peserta didik yang karakternya bagus, kedua yang karakternya sedang dan ketiga karakternyta yang buruk dan informasi ini guna untuk memperdalam dan memperjelas informasi atau data yang diperlukan peneliti. Kedua, observasi. Observasi yaitu pengamatan secara langsung kelapangan, dengan guna untuk mendapatkan informasi atau sebuah data yang diperlukan dalam penelitian. Data yang dikumpulkan seperti cara pembiasan guru dalam membentuk karakter peserta didik. Ketiga, dokumentasi. Dokumentasi diambil dari foto kegiatan dalam pembentukan karakter peserta didik.

Analisis data dilakukan dengan cara memilih data mana saja yang dibutuhkan dalam sebuah penelitian. Data yang sudah diperolah dari lapangan maka di analisis untuk menjawab sebuah permasalahan penelitian. Tahap pengolahan data: Pertama, pengumpulan data dari pendidik khusus kelas wusto dan peserta didik dengan 3 kategori terhadap implikasi pendidikan karakter. Setelah data terkumpul maka dijadikan sebuah informasi dalam bentuk narasi. Kedua, reduksi data yaitu pengelompakan infomasi penting yang sesuai dengan masalah penelitian. Ketiga, analisis data yaitu dengan gambaran hasil penelitian seperti data dalam bentuk deskripsi, data yang dalam bentuk deskripsi dibandingkan dengan landasan teori, selanjutnya pengambilan kesimpulan oleh peneliti. Keempat, penyajian sebuah data. Yaitu data yang dianalisis diinterpretasikan sesuai data yang diperoleh dari informan terhadap masalah penelitian tentang pembiasaan dari pendidik terhadap peserta didik dalam pembentukan karakter di Madrasah Miftahul Huda Musi Rawas Utara. Kelima, penarikan kesimpulan.

\section{HASIL DAN PEMBAHASAN}

Berdasarkan hasil wawancara, observasi dan dokumentasi pada tanggal 29 juni 2020 didapatkan bahwa penanaman nilai-nilai pendidikan karakter yang diterapkan di Madrasah Miftahul Huda Musi Rawas Utara merupakan nilai ilahiyah dan insyaniyah yang sebenarnya dasar dari pendidikan karakter dengan rujukan atau berpedoman dalam Al-Qur'an dan Assunnah. Nilai ilahiyah seperti; Sholat wajib, sholat sunnah, tadarus, berdzikir, bersholawat dan puasa. Dan Nilai 
insyaniyah itu saling tolong menolong, sopan santun dan menjaga kebersihan. Hal ini menjadi landasan sebuah pendidikan di Madrasah Miftahul Huda Musi Rawas Utara.

Terdapat dalam undang-undang No 20 Tahun 2010 berisi sebuah sistem pendidikan nasional, bahwasannya pendidikan karakter merupakan usaha yang membentuk atau mengembangkan kepribadian atau perilaku seperti ketika berbicara tidak bohong, memiliki intelektual yang bagus, bertanggung jawab, pantang menyerah, disiplin, sopan santun, ikhlas dan amanah. Dalam kutipan Soleha, Adian Husaini, Endin Mujahidin, Didin Saefuddin (2015: 5)

Berdasarkan hasil wawancara, observasi dan dokumentasi didapatkan nilai karakter yang dilakukan di Madrasah Miftahul Huda Musi Rawas Utara yaitu : a) prinsip taqwa, sholat wajib berjamaah dan sholat sunnah, membaca Al-Qur'an, bersholawat; b) berbicara jujur; c) ikhlas membantu sesama teman; d) sopan santun; e) disiplin; f) menjaga kebersihan baik didalam kelas maupun diluar kelas.

Strategi yang dilakukan pendidik pada pendidikan karakter peserta didik yaitu; pertama, pendidikan karakter melalui proses pembelajaran. Proses pembelajaran pendidikan karakter ini harus diaplikasikan kepada semua mata pelajaran, seperti di mata pelajaran Bahasa Arab diajarkan untuk disiplin dan belajar yang sungguh-sungguh. Dan juga seperti di mata pelajaran Akidah Akhlak diimplikasikan tentang berkata yang jujur terhadap teman dan menjaga kebersihan.

Kedua, Keteladanan yaitu melihat sifat atau akhlak Nabi Muhammad yang menjadi suri tauladan umat manusia. Seperti halnya menerapkan konsep keteladanan ini pada peserta didik seperti sopan santun, ramah, bersalaman kepada pendidik dan bahkan perbuatan atau tingkah laku seorang pendidik ditiru oleh peserta didik. Disini pendidik menjadi sosok yang diikuti atau sebagai contoh.

Dimana keteladanan memiliki sebuah makna yaitu sesuatu yang dilihat pada pendidik yang mencerminkan halhal yang baik diikuti seperti perlakuan yang baik, sifat pendidik, ramah dan bertanggung jawabnya pendidik, dan lain sebagainya. Dan hal ini kemudian ditiru oleh siswa dan dicontoh untuk tindakan kesehariannya. Karena itu pendidik dijadikan panutan bagi peserta didik. (Alya Qonita, 2011: 783).

Dan juga sesuai dengan pembiasaan keteladanan dalam penelitian MR Chemuhammad Chemamad (2017: 6) yang mengatakan bahwa konsep keteladanan yang dilakukan oleh guru atau pendidik dalam membentuk karakter siswa atau peserta didik dengan cara memberikan nasehat, akhlak yang baik, mudah tersenyum atau ramah ini sudah diaplikasikan dengan sangat baik diterima atau ditiru oleh peserta didik atau siswa.

Ketiga, Pembiasaan, bahwasannya dengan kebiasaan pendidikan karakter seperti dengan sholat berjamaah, membaca Al-Qur'an, bersholawat, sopan santun, jujur, saling tolong menolong dan senyum sapa ini akan melekat kepada jiwa peserta didik. Bukan hanya dilakukan di dalam Madrasah tetapi dilakukan juga di lingkungan masyarakat luas. Strategi seperti ini sangat membantu agar terciptanya karakter peserta didik yang bagus.

Karena juga diliha dari pengertiannya pembiasaan ini sangat berperan penting dalam pembentukan karakter individu atau peserta didik. Usaha dalam pembiasaan ini dilaksanakan karena faktor keribadian manusia yang yang memiliki sifat lemah dan mudah lupa. Dan kebanyakan pembiasaan itu lahir dari amalan yang sering dilakukan jadi rata-rata bersifat positif (Hidayat, 2016: 9). 
Hasil penelitian ini sesuai dengan penelitian Haeruddin (2019: 10) penelitian yang mengatakan terdapat kelebihan tesendiri dari metode pembiasaan ini jika dibiasakan terhadap peserta didik mengerjakan atau setiap tindakannya dalam kegiatan kesehariannya maka akan membentuk karakter peserta didik dengan hal-hal yang positif atau baik.

$$
\text { Keempat, pemberian sebuah }
$$
motivasi dan pemberian aturan, bahwasannya sebuah motivasi ini dapat meningkatkan karakter anak didik dengan baik. Dan sebuah aturan yang ditemukan di Madrasah Miftahul Huda Musi Rawas Utara yang sangat unik yaitu apabila peserta didik tidak menjalankan atau melakukan pembiasan karakter maka diberikan hukuman seperti keliling masjid Madrasah selama 7 (tujuh) kali putaran atau lari-lari kecil dengan membaca zikir atau kalimat talbiyah. Dengan maksud pendidik mengetahui mana peserta didik yang akhlaknya atau karakternya kurang baik. Dan dengan itu juga dapat manfaat tersendiri yaitu membuat peserta didik terbiasa membaca zikir atau kalimat talbiyah dan olahraga agar tubuh sehat.

Dan penguatan motivasi ini juga sesuai dengan penelitian oleh Rosikum (2018: 12) bahwasannya dalam memberikan sebuah nasehat atau motivasi ini jika diberikan oleh pendidik secara terus menerus maka akhirnya dapat membentuk penguatan karakter peserta didik menjadi pribadi yang baik dan menjadikan peserta didik melakukan hal-hal yang positif.

Maka dari itu faktor pendukung dari pendidikan karakter ini yaitu kerja keras pendidik dalam membentuk pembiasan dan kemauan peserta didik yang kuat. Sedangkan faktor penghambatnya yaitu dari segi lingkungan masyarakat luas yang belum dapat mengontrol kemauan anak didik.

Maka dari itu pendidikan karakter bertujuan agar dapat melekatkan dan membuat karakter individu lebih baik dan maksimal lagi, yaitu sesuai standar kompetensi lulusan pendidikan. Pendidikan karakter ini mengarah pada perilaku peserta didik dan kebiasan peserta didik.

Pendidikan karakter juga memiliki makna bahwasannya program atas sesuatu yang menanamkan sebuah nilainilai karakteristik yang melekat pada siswa, baik pula tentang pengetahuan, tingkat kesadaran interpersonal, serta kemauan yang kuat untuk merealisasikan nilai-nilai, baik itu kepada diri sendiri, kepada masyarakat luas, dan bahkan pula kepada Tuhan yang Maha Esa dan menjadi karakteristik yang baik (Aunillah, 2011: 19).

Dan juga dibantu dengan pembiasan dalam pembentukan karakter inilah yang sangat berperan penting. Dikarenakan dengan amalan-amalan yang dilakukan dalam pemberian tugas atau kegiatan yang oleh pendidik ini maka keinginan seseorang akan naik untuk melakukannya. Yaitu dari sebuah prinsip kebiasaan dari sebuah perbuatan kemudian dibiasakan kemudian bisa membentuk karakter anak didik atau peserta didik (Hendriana, et al, 2016: 4). 


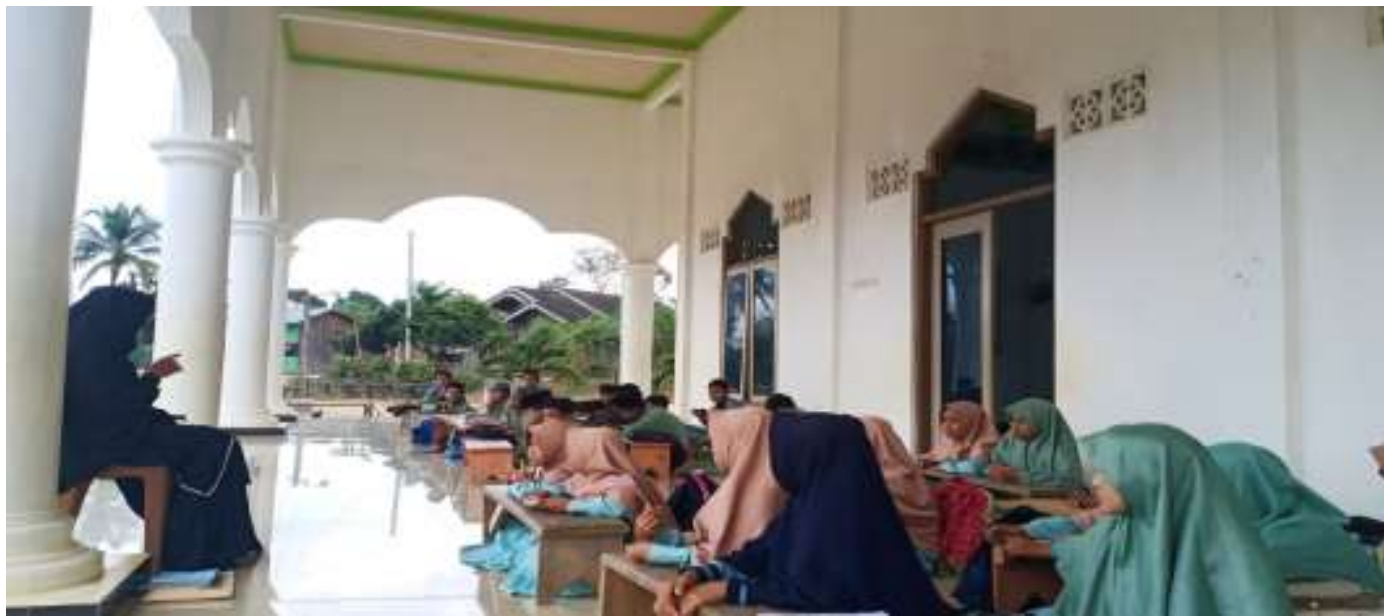

Dokumentasi proses pembelajaran dan pemberian motivasi atau nasehat kepada peserta didik kelas 4 di Madrasah Miftahul Huda Desa Srijaya Makmur Kecamatan Nibung Kabupaten Musi Rawas Utara Sumatera Selatan.

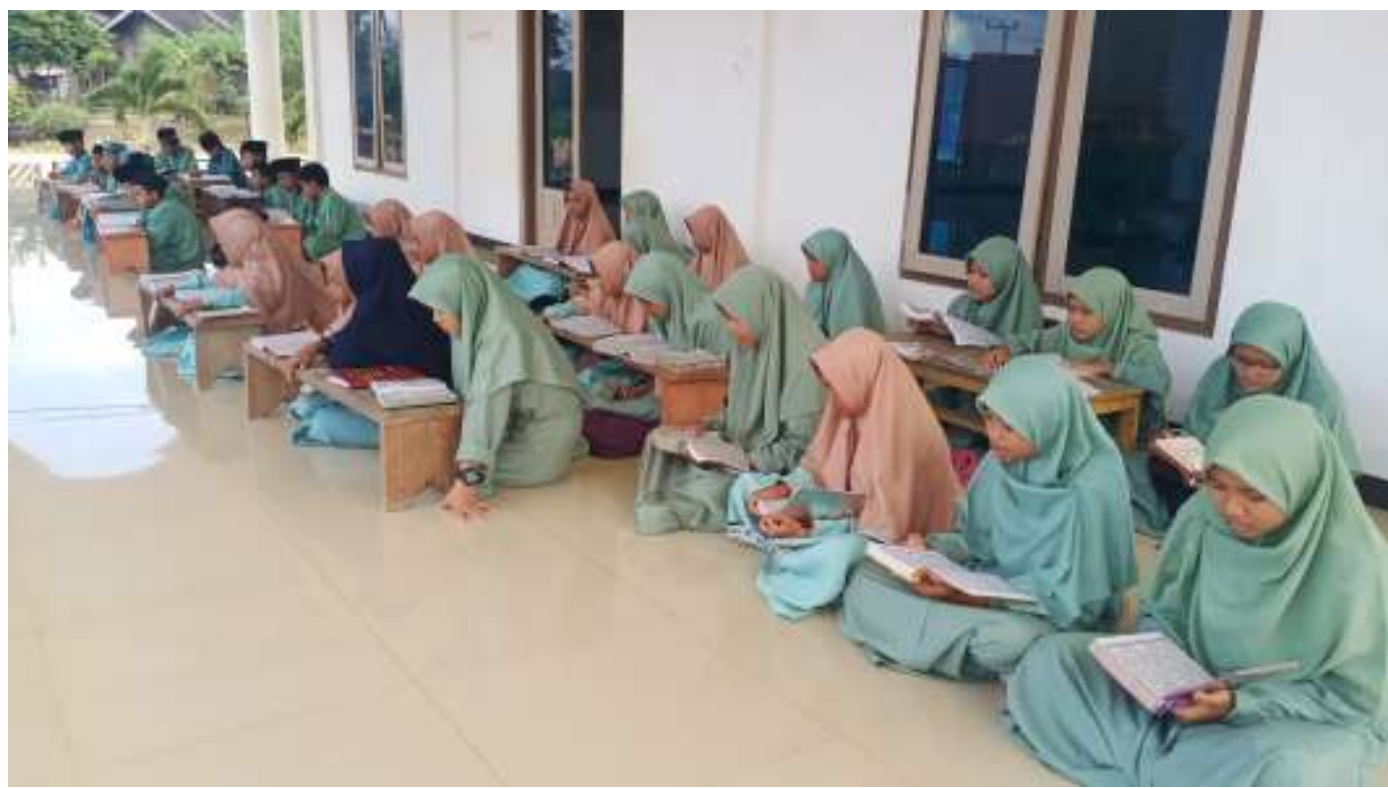

Dokumentasi pada saat Tadarus atau membaca Al-Qur'an pada peserta didik kelas 4 di Madrasah Miftahul Huda Desa Srijaya Makmur Kecamatan Nibung Kabupaten Musi Rawas Utara Sumatera Selatan.

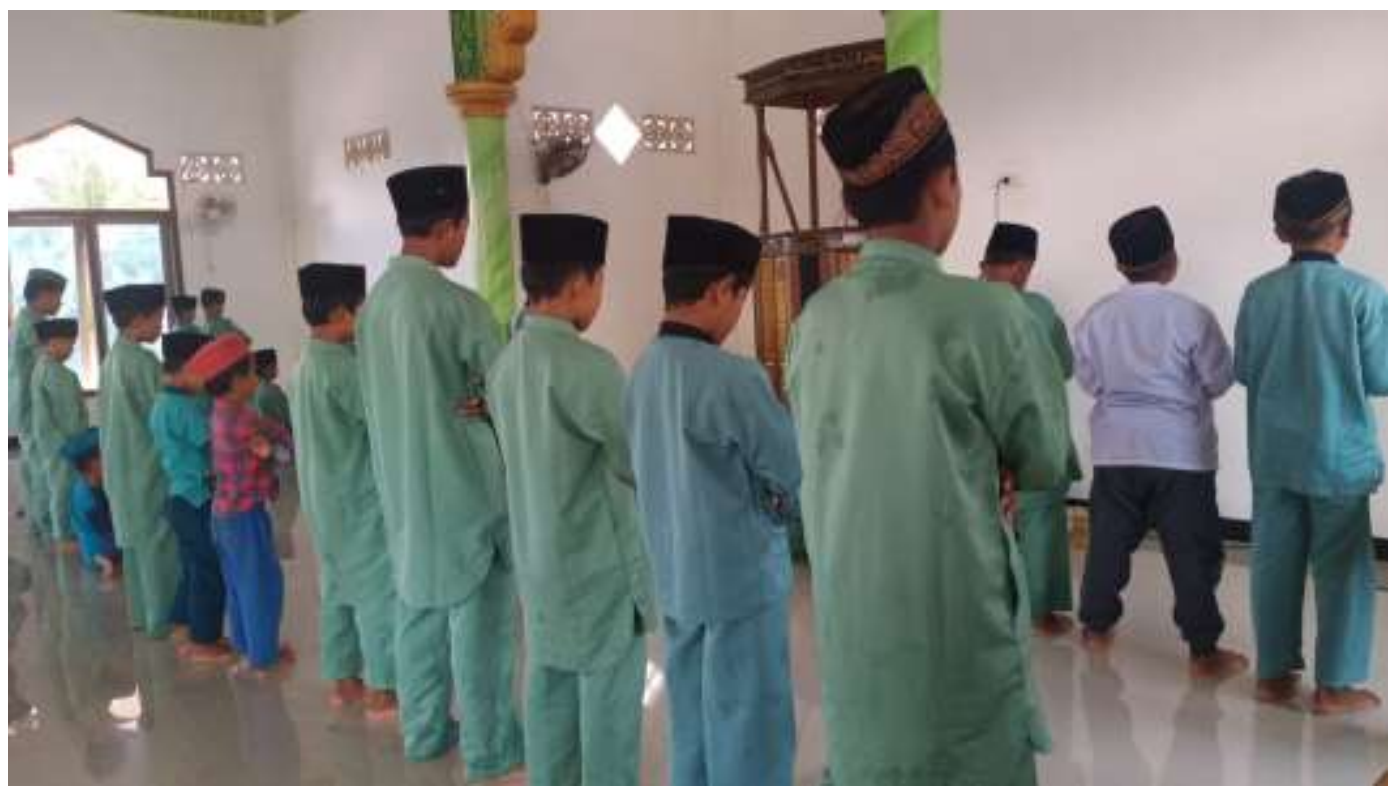


Dokumentasi pada saat pelaksanaan Sholat berjamaah peserta didik kelas 4 di Madrasah Miftahul Huda Desa Srijaya Makmur Kecamatan Nibung Kabupaten Musi Rawas Utara Sumatera Selatan

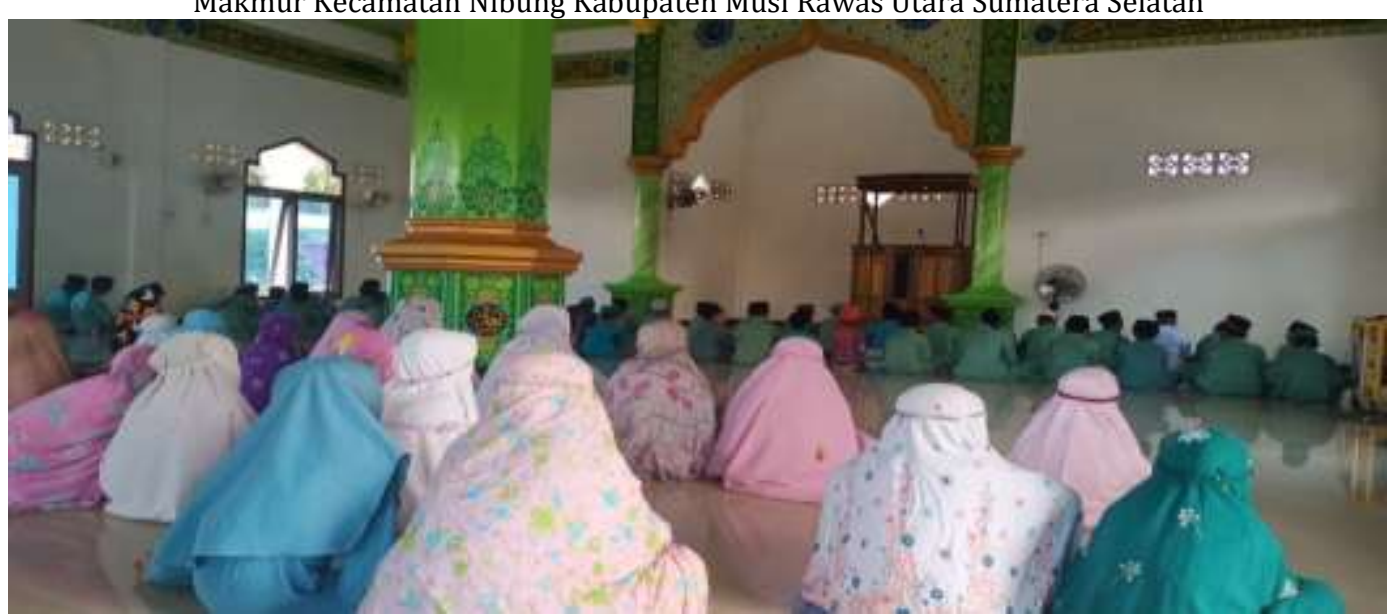

Dokumentasi pada saat Zikir setelah sholat berjamaah pada peserta didik kelas 4 di Madrasah Miftahul Huda Desa Srijaya Makmur Kecamatan Nibung Kabupaten Musi Rawas Utara Sumatera Selatan.

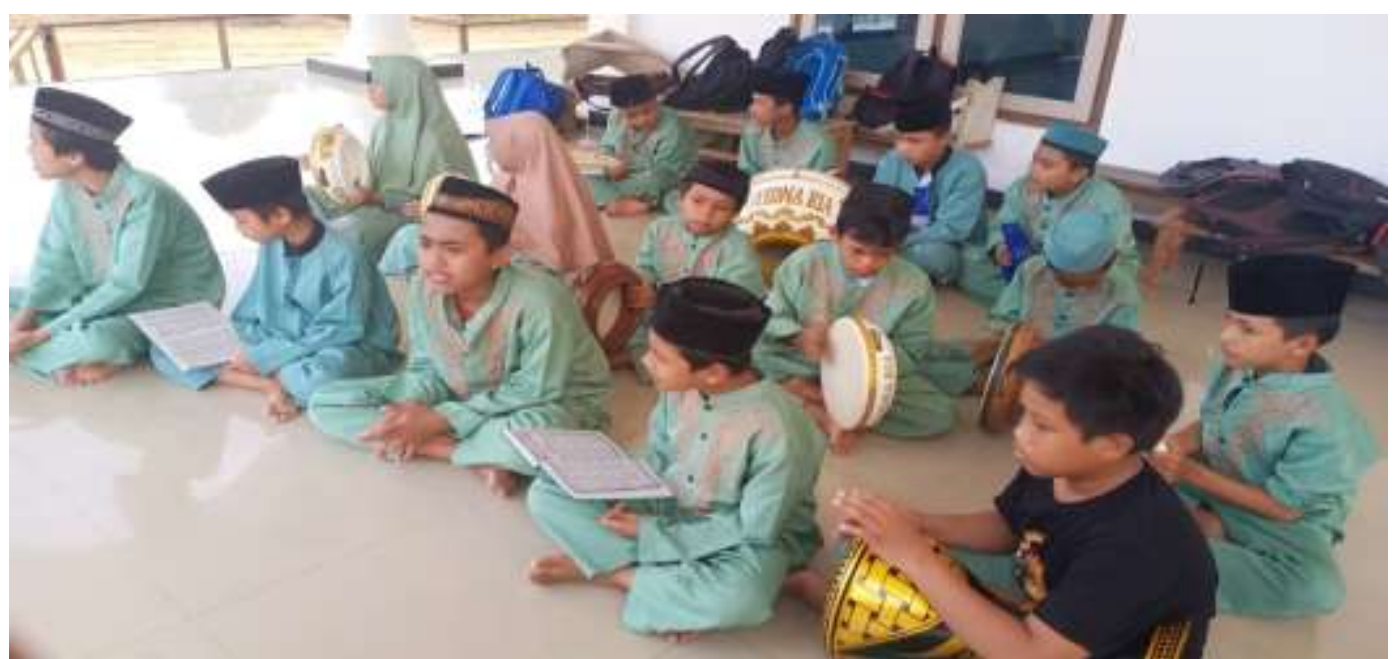

Dokumentasi Saat membaca sholawat pada peserta didik kelas 4 di Madrasah Miftahul Huda Desa Srijaya Makmur Kecamatan Nibung Kabupaten Musi Rawas Utara Sumatera Selatan.

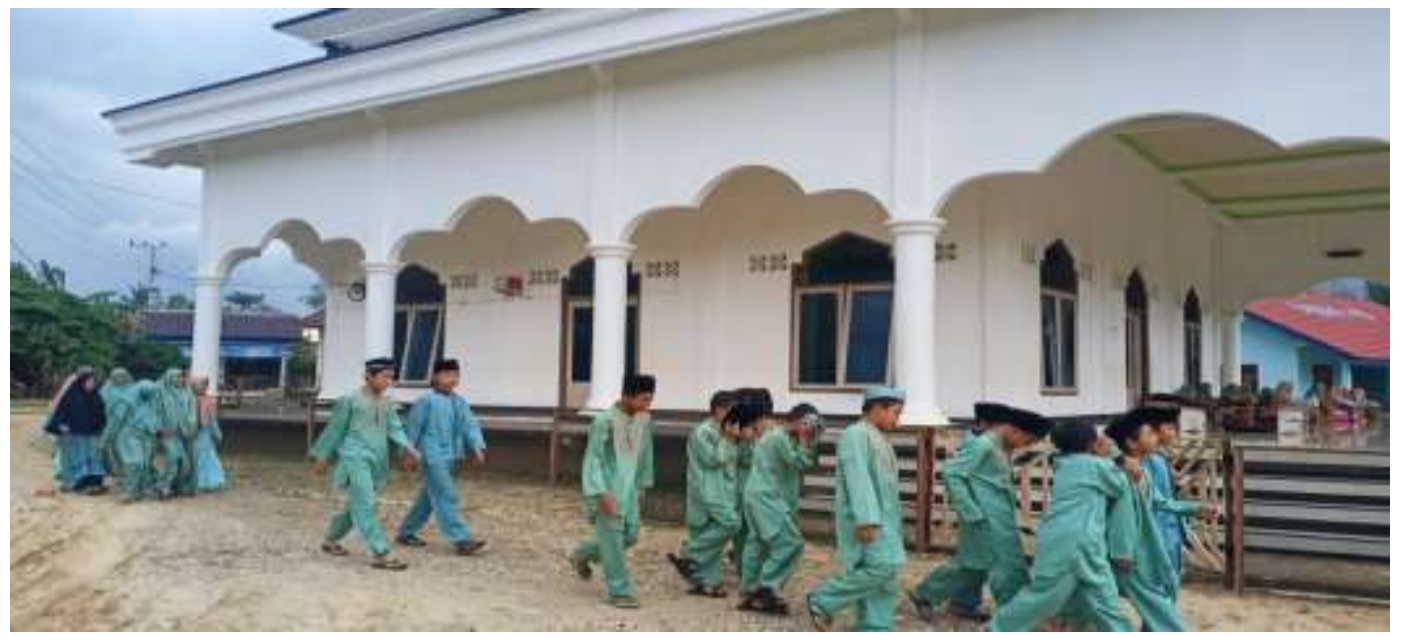

Dokumentasi Saat hukuman keliling masjid sebanyak 7 kali dengan melafalkan zikir dan kalimat talbiyah pada peserta didik kelas 4 di Madrasah Miftahul Huda Desa Srijaya Makmur Kecamatan Nibung Kabupaten Musi Rawas Utara Sumatera Selatan. 


\section{PENUTUP}

Sesuai dengan hasil pembahasan didapatkan bahwasannya pendidikan karakter ini berpedoman dengan AlQur'an dan As-sunnah meliputi menerapkan pertama, nilai peribadahan seperti sholat berjama'ah, sholat sunnah, membaca Al-Qur'an, dan bersholawat. Kedua, pembiasan kepribadian individu seperti berbicara jujur, sopan santun, disiplin, dan suka menolong. Ketiga faktor yang mendukung yaitu dari Usaha pendidik dan kemauan peserta didik dengan cara metode keteladanan. Dan faktor penghambatnya yaitu dari lingkungan dan individu yang belum bisa mengontrol kemauannya untuk hidup bebas. Dengan tambah memaksimalkan pembiasan pembentukan karakter maka akan semakin banyak karakter peserta didik yang baik dan sesuai dengan yang diharapkan oleh pendidik.[]

\section{DAFTAR RUJUKAN}

Abbdullah, Yatimin. Studi Akhlak Dalam Prespektif Al-Qur'an. Jakarta: Amzah, 2007.

Arikunto, Suharsimi. Prosedur Penelitian Suatu Pendekatan Praktek. Jakarta: Rineka Cipta, 2012.

Basri, Hasan. Penanaman Nilai-nilai Multicultural Melalui Pendidikan Agama Islam di SMK Triatma Jasa Semarang. Tesis, UIN Walisongo Semarang, 2017.

Chemamad, MR Chemuhammad. Keteladanan guru dalam membentuk Akhlak karimah peserta didik TPQ Al-Falah Perrumahan Bakti Persada Indah (BPI). Semarang, 2017.

Fajrussalam, Hisny, Uus Ruswandi, Mohammad Erihadiana. "Strategi Pengembangan Pendidikan Multikultural Di Jawa Barat." Jurnal Edueksos 9.1 (2020) : 4-5.

Haeruddin. "Implementasi Pendidikan Karakter di Pondok Pesantren An-
Nurîyah Bonto Cini' Kabupaten Jeneponto Provinsi Sulawesi Selatan." al-thariqah 4.1 (2019): 2-6 Hakim, Rosniati. "Pembentukan Karakter Peserta Didik Melalui Pendidikan Berbasis Al-Quran." Jurnal Pendidikan Karakter IV.2, (2014) : 12.

Hasan Baharun dan Mahmudah. "Konstruksi Pendidikan Karakter Di Madrasah Berbasis Pesantren". Jurnal Mudarrisuna 8.1 (2018): 2-4.

Hendriana, Evinna Cinda, Arnold Jacobus. "Implementasi Pendidikan Karakter Di Sekolah Melalui Keteladanan dan Pembiasaan". Jurnal Pendidikan Dasar Indonesia 1.2 (2016): 4-7.

Hidayat, Nur. "Implementasi Pendidikan Karakterr Melalui Pembiasaan di Pondok Pesantren Pabelan". Jurnal Pendidikan Sekolah Dasar 2.1 (2016): 9-11.

Isna Aunillah, Nurla. Panduan Menerapkan Pendidikan Karakter di Sekolah. Jogjakarta: Laksana, 2011.

Jusar, Ira Rahmayuni. "Implikasi NilaiNilai Karakter Dalam Pembelajaran Matematika Di Sekolah Dasar, Fakultas Keguruan Dan Ilmu Pendidikan Universitas Bung Hatta". Artikel.

Miftah Syarif, Hamzah, Mustofik. "Pelaksanaan Pendidikan Karakter dalam Pembelajaran PAI di SMK Hasanah Pekanbaru". Jurnal AlThariqah 1.1 (2016): 6-8.

Muntaqo, Rifqi. 'Tradisi Isra' Mi'raj Sebagai Upaya Pembentukan Karakter Generasi Millenial." Jurnal Paramurobi 1.2 (2018): 4-7.

Qonita, Alya. Kamus Bahasa Indonesia Untuk Pendidikan Dasar. Jakarta : PT indah jaya, 2011.

Rosikum. "Peran Keluarga Dalam Implementasi Pendidikan Karakter Religius Anak". Jurnal Kependidikan 6.2 (2018): 12-13. 
Sa'adillah, Rangga. "Pendidikan Karakter Menurut Kh. Wahid Hasyim." Jurnal Pendidikan Agama Islam 3.2 (2015): 6-7.

Soleha, Adian Husaini, Endin Mujahidin, Didin Saefuddin. "Implementasi Pengembangan Karakter Keagamaan Dan Potensi Kecerdasan Anak Usia Dini." Ta'dibuna 4.2 (2015): 5-6.

Sugiono. Metodologi Penelitian Kuantitatif Kualitatif dan R\&D. Bandung: Alfabeta, 2012.

Tarsono. "Character Building Pada Manusia”. Jurnal Ilmiah Psikolog 1.1 (2014): 3-4.

Undang- Undang Ri No 20 Tahun 2003. Tentang Sistem Pendidikan Nasional. Jakarta: Departemen Pendiidkan Nasional RI, 2013.

Zakky Mubarok, Ahmad. "Model pendekatan pendidikan karakter di pesantren terpadu". Jurnal Ta'dibuna 8.1 (2019): 1-2. 